\title{
Шлыкова Е.В.
}

\section{Противодействие терроризму как адаптация к рискам современности: социальная сущность и субъекты процесса}

\author{
Институт социологии Федерального научно-исследовательского \\ социологического центра Российской академии наук \\ ул. Кржижановского, 24/35, корп. 5, г. Москва, 117218, Россия \\ shlykova70@yandex.ru \\ ORCID iD: 0000-0002-2875-271X
}

\section{Статья поступила 28 сентября 2019 г.; принята 8 декабря опубликована 30 декабря}

\begin{abstract}
Аннотация. Исходным в статье является представление о террористической угрозе как одном из социальных рисков современности, модифицирующем привычную среду и требующем адаптации. Предложен подход к противодействию терроризму как процессу институционально-гражданской адаптации к рискогенной среде. Представлен анализ тенденций и динамики процесса адаптации к риску терроризма в России основных субъектов противодействия: социальных институтов и гражданского общества в 2005-2018 годах. Содержательное развитие российского антитеррористического законодательства, положительная динамика качества действующего механизма противодействия способствуют активной адаптационной стратегии и высокому уровню адаптации институциональных субъектов к риску терроризма. Вместе с тем, реактивный характер российского антитеррористического законодательства приводит к недостаточной реализации принципов приоритета мер предупреждения терроризма и сотрудничества государства с гражданами в противодействии ему. Невысокий уровень самооценок защищенности от терактов, неготовность населения к участию в противодействии терроризму, недоверие институциональным субъектам и стремление переложить на них ответственность за процесс противодействия обусловливают пассивную адаптационную стратегию и низкий уровень адаптированности населения России к риску терроризма. Адаптационная асимметрия в скорости и успешности адаптации институциональных субъектов и населения тормозит процесс противодействия терроризму в целом. Предлагаются научные и практические меры, направленные на восстановление баланса адаптационных стратегий и ресурсных потенциалов субъектов противодействия терроризму.
\end{abstract}

Ключевые слова: террористическая угроза; противодействие терроризму; антитеррористическое законодательство; субъекты противодействия; гражданское участие; адаптация; адаптационная стратегия; риск, рискогенная среда.

\footnotetext{
Информация для цитирования: Шлыкова Е. В. Противодействие терроризму как адаптация к рискам современности: социальная сущность и субъекты процесса // Научный результат. Социология и управление. 2019. Т. 5, N 4. C. 103-118. DOI: 10.18413/2408-9338-2019-5-4-0-9
} 


\author{
Institute of Sociology, \\ Federal Center for Theoretical and Applied Sociology, \\ Russian Academy of Sciences \\ bld. 5, 24/35 Krzhizhanovsky St., Moscow, 117218, Russia \\ shlykova70@yandex.ru \\ ORCID iD: 0000-0002-2875-271X
}

\title{
Received September 28, 2019; accepted December 8, 2019 published December 30, 2019
}

\begin{abstract}
The starting point of the article is the idea of the terrorist threat as one of the social risks of modernity, modifying a familiar environment and requiring adaptation. Proposed approach to counter-terrorism as a process of institutional and civil adaptation to the risky environment. The article presents the analysis of trends and dynamics of the process of adaptation to the risk of terrorism in Russia of the main subjects of counteraction: social institutions and civil society in 2005-2018. The substantial development of the Russian anti-terrorist legislation, the positive dynamics of the quality of the existing counteraction mechanism contribute to an active adaptation strategy and a high level of adaptation of institutional subjects to the risk of terrorism. At the same time, the reactive character of the Russian anti-terrorist legislation leads to insufficient implementation of the principles of priority measures to prevent terrorism and cooperation between the state and citizens in countering it. The low level of self-assessment of protection from terrorist attacks, the unwillingness of the population to participate in countering terrorism, distrust of institutional actors and the desire to shift all responsibility for the process of counteraction to them cause a passive adaptation strategy and a low level of adaptation of the Russian population to the risk of terrorism. The adaptive asymmetry in the speed and success of adaptation of institutional actors and the population hinders the process of countering terrorism as a whole. Scientific and practical measures aimed at restoring the balance of adaptation strategies and resource potentials of counter-terrorism subjects are proposed.
\end{abstract}

Keywords: terrorist danger; counteraction to terrorism; anti-terrorism legislation; subjects of counteraction; civic participation; adaptation; adaptation strategy; risk; risky environment.

Information for citation: Shlykova E. V. (2019), "Countering terrorism as adaptation to risks of the present: social essence and subjects of the process", Research Result. Sociology and management, 5(4), 103-118. DOI: 10.18413/2408-9338-20195-4-0-9

Введение (Introduction). В последние годы в мире отмечается опасная динамика роста количества и «качественного усовершенствования» террористических атак. Основные тенденции современного терроризма, представляющие угрозу национальной безопасности России и ее населению, отражены в «Концепции противо- 
действия терроризму в Российской Федерации» ${ }^{1}$. Масштаб и высокая вероятность разрушительных последствий террористической угрозы обусловливают актуальность поиска адекватных мер противодействия терроризму, что отражается в современном научном дискурсе. Анализ научной литературы за последние несколько лет показывает, что проблема противодействия терроризму находится в зоне внимания специалистов в области юриспруденции и права, социальной психологии и социологии.

Методология и методы (Methodology and methods). Правовой аспект включает изучение специфики российского законодательства, направленного на регулирование антитеррористической, антиэкстремистской деятельности, обоснование путей его усовершенствования (Аккаева, 2015; Кочои, 2016); анализ практики правоприменения в оперативно-розыскной и уголовно-процессуальной работе (Бутаев, 2015); формирование комплексной правовой системы поддержки деятельности противодействующих терроризму субъектов (Сембекова, 2018). Психологи в основном исследуют процессы формирования антитеррористического и антиэкстремистского сознания (Яхьяев и др., 2018).

Мониторинговые социологические замеры включают риск терроризма в рейтинговый перечень угроз наряду с другими внутренними и внешними угрозами, а борьбу с терроризмом - в перечень оценки динамики и качества изменений в различных сферах общественной жизни (Российское общество..., 2017). Целевые социологические исследования рассматриваемой проблемы можно свести к следующим основным: обоснование социальной сущности терроризма (Щебланова, 2012); оценка населением остроты террористической угрозы, эффективности работы государ-

\footnotetext{
${ }^{1}$ Концепция противодействия терроризму в Российской Федерации: утверждена Президентом РФ 05.10.2009 г. // Консультант-плюс. URL: http://www.consultant.ru/document/cons_doc_LAW_92779/ (дата обращения: 31.07.2019).
}

ственных органов по противодействию терроризму и уровень доверия к ним ${ }^{2}$; анализ причин, факторов и каналов вовлечения населения в террористические и экстремистские организации и обеспечение профилактики терроризма и экстремизма (Маркин, 2014).

Подчеркивая масштабность проблемы, приходится признать, что социологические исследования противодействия терроризму последних лет, как правило, проводятся в отдельных регионах и не дают полной картины представлений населения о сути процесса, не учитывают его динамику. Опросы общественного мнения, напротив, отслеживают динамику представлений населения о терроризме и борьбе с ним, но не проводят анализ взаимосвязи оценок террористической угрозы населением с показателями, характеризующими процесс противодействия.

Исходным для анализа в статье является представление о террористической угрозе как одном из социальных рисков современности, модифицирующем привычную, безопасную среду и требующем адаптации: «терроризм влечет за собой обширные далеко идущие последствия..., сила же социальной системы проявляется в ее возможности принять террористический вызов..., преодолеть трудности благодаря адаптивным модификациям» (Щебланова, 2013: 271).

В статье предлагается понимание противодействия терроризму на базе методологии анализа адаптационных процессов в трансформирующемся обществе. Адаптация в целом трактуется как процесс «активного освоения» среды, направленного на достижение «гармонии» между субъектом и средой (Козырева, 2004). В рискогенной среде целью адаптации является

\footnotetext{
${ }^{2}$ Террористическая угроза на сирийском фоне // ВЦИОМ. Пресс-выпуск 11.09.2018 г. https://wciom.ru/index.php?id=236\&uid=9302 (дата обращения: 15.08.2019); Проблема терроризма в представлениях россиян // Левада-Центр. Пресс-выпуск 12.02.2014 г. URL: https://www.levada.ru/2014/02/12/problema-terrorizma-vpredstavleniyah-rossiyan/ (дата обращения: 15.08.2019).
} 
способность предвидеть возможные ущербы и справляться с неизбежными (Мозговая, Шлыкова, 2014).

Сущность терроризма состоит в институционально-гражданском характере предотвращения и противодействия. Иными словами, ответственность за противодействие терроризму несут основные субъекты социальной жизнедеятельности: как социальные институты, так и гражданское общество. Применительно к террористической угрозе адаптация на институциональном уровне анализируется через правоприменение, на уровне гражданского общества - через оценки населением своей защищенности, качества и практики противодействия терроризму, доверия институциональной среде, готовности к гражданскому участию в сфере борьбы с террористическими и экстремистскими проявлениями.

Цель статьи - выявить тенденции в динамике процесса противодействия терроризму в России как адаптации к рискогенной среде, трансформирующейся под воздействием террористической угрозы. Для этого охарактеризуем представления россиян о террористической угрозе; определим «социальный запрос» на определенные аспекты процесса противодействия терроризму; проанализируем их динамику за последние годы.

Эмпирическую базу анализа составляют данные общероссийского социологического опроса, выполненного группой специалистов Института социологии $\mathrm{PAH}^{3}$ под руководством директора, академика PAH, доктора философских наук, М. К. Горшкова и руководителя сектора проблем риска и катастроф, кандидата философских наук А. В. Мозговой осенью 2005 года. Квотная выборочная совокупность репрезентировала взрослое население России в возрасте от 18 лет и старше по полу, возрасту, типу поселения и характеру занятости и составляла 3000 респон-

${ }^{3} \mathrm{C} 2017$ года Институт социологии РАН реорганизован в Институт социологии ФНИСЦ РАН. дентов. Опрос населения России проводился методом формализованного интервью. Инструментарий разработан М. К. Горшковым и А. В. Мозговой.

На основе данных этого исследования проанализируем специфику «социального запроса» россиян на противодействие терроризму по следующим показателям: оценка населением террористической угрозы; оценка россиянами правовой базы противодействия терроризму; субъекты противодействия терроризму и оценка их деятельности; гражданское участие как ресурс противодействия терроризму.

На основании вторичного анализа данных социологических исследований коллег, опросов общественного мнения, официальной статистики, содержательного анализа изменений и дополнений антитеррористического законодательства осуществим анализ динамики показателей «социального запроса» россиян на противодействие терроризму в период с 2006 года по настоящее время. Полагаем, что предложенный ретроспективный подход позволит выявить позитивные и негативные тенденции процесса противодействия терроризму в России и наметить пути его совершенствования, направленные на повышение адаптированности субъектов противодействия к риску терроризма.

Научные результаты и дискуссия (Research Results and Discussion).

Оиенка террористической угрозы и динамика опасений россиян. К 2005 году население России многократно сталкивалось лицом к лицу с террористическими атаками и имело опыт переживания крупнейших терактов по количеству жертв и пострадавших ${ }^{4}$.

По данным опроса Института социологии РАН в 2005 году подавляющее большинство респондентов утверждали, что по тем или иным причинам справиться с терроризмом в современном мире невоз-

\footnotetext{
${ }^{4}$ Теракты, совершенные в России // Википедия. Дата обновления: 09.08.2019. URL: https://ru.wikipedia.org/?oldid=101513875 (дата обращения: 09.08.2019).
} 
можно (34\% - из-за экономических, геополитических, религиозных и других противоречий; $16 \%$ - в силу природной агрессивности и жестокости людей; 29\% - терроризм возможно ограничить, но не искоренить полностью). Вместе с тем, около трех четвертей респондентов считали, что не существует мер, которые могут полностью исключить угрозу терроризма ни в нашей стране (74\%), ни в мире (76\%).

В момент опроса совсем не защищенными от действий террористов ощущали себя 74\% россиян, частично защищенными - 23\%, полностью защищенными $-3 \%$. Оценивая вероятность терактов, более половины россиян (54\%) полагали, что теракт в том месте, где они проживают, вполне возможен, 38\% - маловероятен, и только $8 \%$, что практически невозможен. $14 \%$ респондентов довольно часто ловили себя на мысли, что они или члены их семей могут оказаться жертвами терактов, $50 \%$ утверждали, что такие мысли их посещают в основном после терактов, $22 \%$ и $13 \%$ задумывались об этом редко или практически никогда соответственно. Данные Левада-Центра за тот же год демонстрируют высокий уровень страха россиян оказаться жертвами теракта: $28 \%$ - «очень боюсь», 50\% - «в какой-то мере опасаюсь», 9\% - «уверен, что ни со мной, ни с моими близкими этого не случится», $10 \%$ - не задумывались об этом ${ }^{5}$.

Углубленный анализ наличия статистически значимой связи индикаторов внутри показателя «оценка террористической угрозы населением России» показывает, что ведущим фактором выступает степень опасений стать жертвой теракта. Именно ее динамику с момента опроса по настоящее время мы включили в дальнейший анализ (рис. 1).

В рассматриваемый период времени уровень опасений населения России стать жертвами терактов в сумме остается прак-

${ }^{5}$ Проблема терроризма в представлениях россиян // Левада-Центр. Пресс-выпуск 12.02.2014 г. URL: https://www.levada.ru/2014/02/12/problema-terrorizma-vpredstavleniyah-rossiyan/ (дата обращения: 15.08.2019). тически неизменным и составляет, также, как и в 2005 году, чуть более 70\%. Линии тренда позволяют отследить, что динамика опасений связана в основном с вариацией признака «очень боюсь», в то время как средний уровень опасений россиян существенным образом не меняется. Причины достаточно резких спадов общего уровня опасений населения к настоящему времени социологами не исследовались и, безусловно, требуют глубокого изучения. Одна из гипотез, отраженных в научной литературе, состоит в предположении о снижении актуальности целого ряда угроз (в том числе и террористической) вследствие актуализации в массовом сознании опасений роста цен, снижения доходов, потери работы и других, связанных с переживанием экономических кризисов (Российское общество.., 2017), что вполне соответствует зафиксированным на рис. 1 спадам опасений россиян стать жертвами терактов в 2009, 2014 и 2018 годах.

В недавней работе нам удалось обосновать, что пороговое значение безопасности может определяться наличием/отсутствием тревожности в сознании социальных субъектов и, в случае наличия, указывать на низкий уровень адаптированности к рискогенной среде (Шлыкова, 2018). Поэтому в рамках методологии анализа адаптационных процессов зафиксированные достаточно высокий уровень опасений россиян в отношении террористической угрозы и практически отсутствующая динамика этого показателя указывают на низкий уровень адаптированности населения к риску терроризма на протяжении длительного времени.

Оченка россиянами правовой базы противодействия терроризму, динамика ее развития и современное состояние. На момент опроса Института социологии РАН в 2005 году практически ничего не знали о российских законах, регулирующих процесс борьбы с терроризмом, 62\% россиян; кое-что знали $34 \%$, хорошо осведомлены оказались 4\% опрошенных. Среди осведомленных в той или иной степени об ан- 
титеррористическом

законодательстве только $8 \%$ респондентов полагали, что правовая база борьбы с терроризмом в России достаточна, 64\% указывали на необходимость некоторой ее корректировки, 28\% считали, что правовая база требует кардинальных изменений. В частности, респондентам задавался вопрос об изменении меры ответственности для террористов, пособников и сочувствующих (таблица 1).

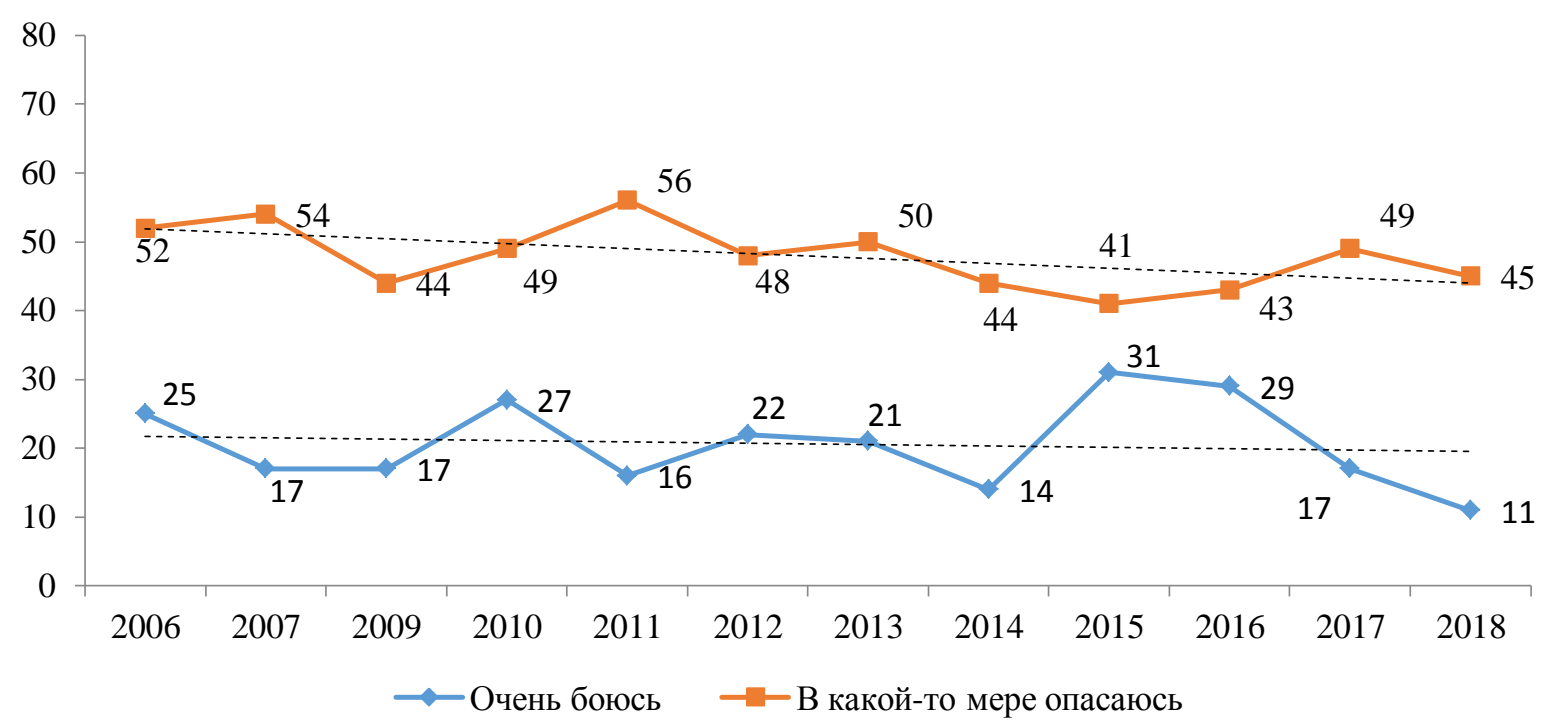

Рис. 1. Динамика высоких и средних оценок опасений россиян стать жертвами теракта (2006-2018) ${ }^{1}, \%$ от количества опрошенных

Fig. 1. Dynamics of high and average estimates of the fear of Russians to become victims of a terrorist attack (2006-2018), \% of the number of respondents

Таблица 1

Table 1

Представления россиян об изменении меры ответственности для террористов, пособников и сочувствующих (\% от количества опрошенных)

Russians' views about changing the measure of responsibility for terrorists, accomplices and sympathizers (\% of the number of respondents)

\begin{tabular}{|c|c|c|c|}
\hline \multirow[b]{2}{*}{$\begin{array}{c}\text { Категории субъектов } \\
\text { террористической угрозы }\end{array}$} & \multicolumn{3}{|c|}{ Мера ответственности } \\
\hline & $\begin{array}{c}\text { Смягчение } \\
\text { уголовной } \\
\text { ответственности }\end{array}$ & $\begin{array}{c}\text { Ужесточение } \\
\text { уголовной } \\
\text { ответственности }\end{array}$ & $\begin{array}{c}\text { Применение } \\
\text { смертной казни }\end{array}$ \\
\hline Террористы & 1 & 44 & 55 \\
\hline $\begin{array}{l}\text { Пособники (распространители } \\
\text { экстремистских идей) }\end{array}$ & 3 & 83 & 14 \\
\hline $\begin{array}{l}\text { Сочувствующие (те, кто знал } \\
\text { и не сообщил о готовящихся } \\
\text { терактах или пропаганде экс- } \\
\text { тремистских идей) }\end{array}$ & 4 & 87 & 9 \\
\hline
\end{tabular}

${ }^{1}$ График построен на основании данных из источника: Террористическая угроза на сирийском фоне // ВЦИОМ. Прессвыпуск 11.09.2018 г. URL: https://wciom.ru/index.php?id=236\&uid=9302 (дата обращения: 15.08.2019). 
Представленные нами данные 2005 года подтверждаются полученными в тот же период времени результатами коллег, в соответствии с которыми большинство населения России поддерживает жесткую тактику борьбы с террористами и их пособниками и значительно меньшая часть «придерживается мнения о том, что нужно следовать либо миротворческой, либо «изоляционистской» тактике ведения борьбы» (Грязнова, 2005: 29), то есть имеет место «социальный запрос» на силовые меры противодействия. Далее проанализируем динамику развития российской правовой базы противодействия терроризму.

Основу правовой базы борьбы с терроризмом в России составляет Федеральный закон от 6 марта 2006 г. №35-Ф3 «О противодействии терроризму» ${ }^{1}$, который «устанавливает правовые и организационные основы противодействия терроризму в Российской Федерации, принципы, субъектов противодействия терроризму, правовой режим контртеррористической операции, основы международного сотрудничества Российской Федерации в области борьбы с терроризмом» (Анищенко, 2006: 87). Во исполнение Закона в последующие годы подготовлен и принят целый ряд других федеральных законов, нормативных правовых актов Президента РФ, Правительства РФ, других федеральных органов государственной власти (Косарев, 2016), а также международных соглашений, «направленных на предупреждение, пресечение и раскрытие преступлений террористического характера» (Соболев, 2010: 25).

Однако аналитики правовых основ противодействия терроризму, отмечают нестабильность российского законодательства, связанную, прежде всего, с быстро меняющимися видами и способами террористической деятельности и неоптимальностью уже принятых законодательных решений (Кочои, 2016). Так, Федеральный

${ }^{1} \mathrm{O}$ противодействии терроризму: Федеральный закон от 06.03.2006 г. № 35-Ф3 // Российская газета. 2006. 10 марта. URL: https://rg.ru/2006/03/10/borba-terrorizm.html (дата обращения: 10.08.2019). закон «О противодействии терроризму»к концу 2015 года был изменен или дополнен 14 раз: неоднократно менялось определение понятия «террористический акт», корректировалось нормативное понимание его целей, расширялись трактовки понятий «террористическое преступление» и «террористическая организация» (Кочои, 2016). Расширение нормативных понятий «террористическое преступление» и «террористическая организация» привели к необходимости соответствующих изменений и дополнений в Уголовный кодекс РФ в части преступлений террористической направленности. Анализ динамики внесенных в Уголовный кодекс РФ поправок «позволяет констатировать последовательное усиление уголовной ответственности за подобные проявления через ужесточение санкций за противоправные деяния» (Павлинов, 2014: 123-124): увеличение сроков лишения свободы за публичные призывы к осуществлению экстремистской деятельности и за возбуждение ненависти или вражды, в том числе через СМИ; введение уголовной ответственности за прохождение обучения в целях осуществления террористической деятельности, за организацию террористического сообщества (организации) или участие в них; криминализация публичных призывов к осуществлению действий, направленных на нарушение территориальной целостности Российской Федерации (Павлинов, 2014). Наряду с этим в практику правоприменения относительно преступлений террористического характера введены следующие меры: «запрет на условное осуждение, увеличение максимальных сроков лишения свободы по совокупности преступлений и совокупности приговоров, включение в некоторые санкции такого вида наказания, как пожизненное лишение свободы, отмена сроков давности» (Косарев, 2016: 39). Нововведения в практике правоприменения отражаются на характере динамики преступлений террористической направленности (рис. 2). 


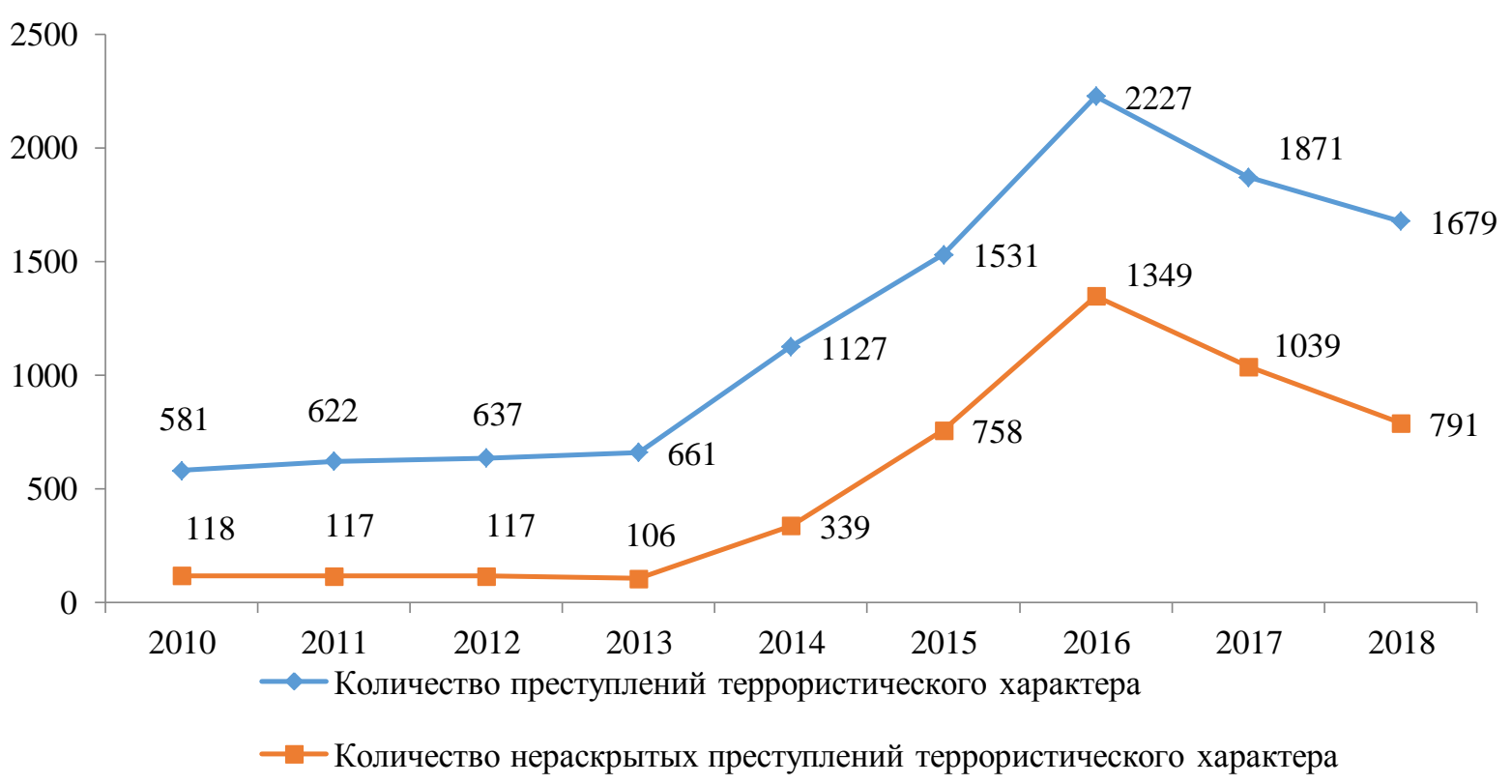

Рис. 2. Динамика количества преступлений террористического характера и их нераскрываемости (2010-2018) ${ }^{1}$

Fig. 2. Dynamics of the number of terrorist crimes and their non-disclosure (2010-2018)

Данные официальной статистики демонстрируют рост количества преступлений террористического характера, обусловленный основными изменениями российского антитеррористического законодательства, пришедшимися на этот период времени, а именно: расширение нормативных понятий «террористическое преступление» и «террористическая организация» и ужесточение наказания за преступления, относящиеся к рассматриваемой категории. «Социальный запрос» населения на силовые меры противодействия терроризму выполнен, причем, заметная в последние три года тенденция к снижению количества преступлений террористического характера, в том числе нераскрытых, свидетельствует об эффективности реализации антитеррористического законодательства в практике правоприменения.

Результаты анализа позволяют утверждать, что динамика развития российской законодательной базы в целом способствует процессу противодействия, а значит, адаптации к риску терроризма. Однако, изменения, вносимые в законодательство но- сят преимущественно реактивный характер и недостаточно реализуют потенциал предусмотренных Федеральным Законом «О противодействии терроризму» принципов, таких как сотрудничество государства с гражданами в противодействии терроризму и приоритет мер предупреждения терроризма (статья 2) ${ }^{1}$.

Субъекты институциональной средbl: оиенка деятельности и доверия. В качестве основных действующих субъектов терроризма принято выделять самих террористов, их пособников, сочувствующих и противодействующую сторону - государственные властные и силовые структуры. В ходе исследования Института социологии РАН в 2005 году россиянам предлагалось оценить меру ответственности различных государственных структур за обеспечение безопасности страны от угроз террористического характера (таблица 2).

${ }^{1} \mathrm{O}$ противодействии терроризму: Федеральный закон от 6.03.2006 г. № 35-Ф3 (действующая редакция) // Консультант-плюс. URL: http://www.consultant.ru/document/cons_doc_LAW_58840/ (дата обращения: 16.08.2019). 
Оценка населением России меры ответственности субъектов институциональной среды за противодействие терроризму и обеспечение безопасности страны

(\% от количества опрошенных)

Assessment by the Russian population of the responsibility of the subjects of the institutional environment for countering terrorism and ensuring the security of the country (\% of the number of respondents)

\begin{tabular}{|l|c|c|c|}
\hline \multirow{2}{*}{$\begin{array}{c}\text { Субъекты институциональной } \\
\text { среды }\end{array}$} & \multicolumn{3}{|c|}{ Мера ответственности } \\
\cline { 2 - 4 } & Полная & Частичная & $\begin{array}{c}\text { Никакой } \\
\text { ответственности }\end{array}$ \\
\hline Армия & 43 & 49 & 8 \\
\hline Государственная Дума & 56 & 40 & 4 \\
\hline Полиция & $\mathbf{7 6}$ & 23 & 1 \\
\hline Правительство РФ & $\mathbf{8 1}$ & 18 & 1 \\
\hline Президент РФ & $\mathbf{8 0}$ & 19 & 5 \\
\hline Совет Федерации & 51 & 44 & 6 \\
\hline Судебная система & 51 & 43 & 1 \\
\hline ФСБ & $\mathbf{9 1}$ & 8 & \\
\hline
\end{tabular}

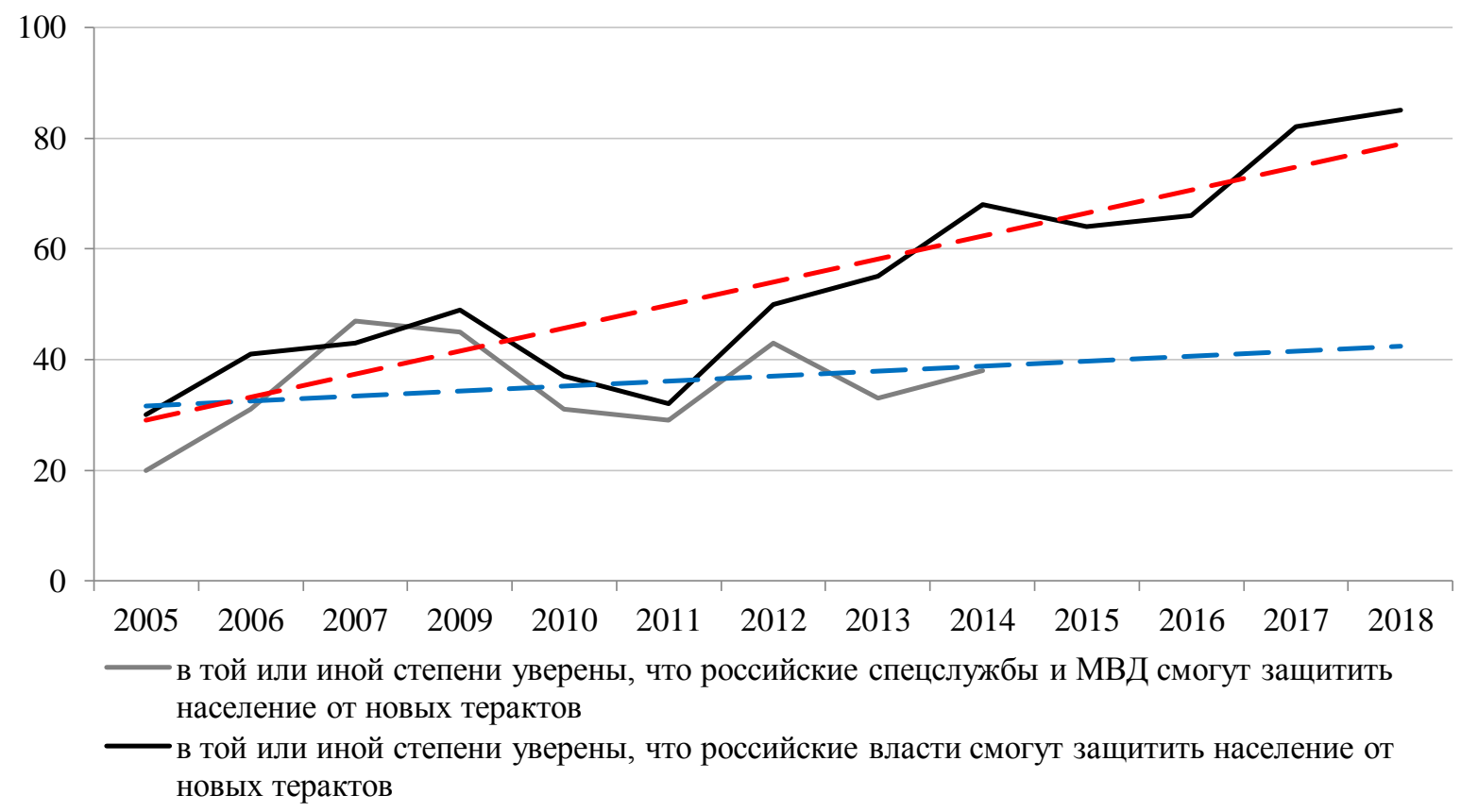

Рис. 3. Динамика уверенности россиян в том, что российские спецслужбы, МВ ${ }^{1}$ и власти смогут защитить население от новых террористических актов (2005-2018), сумма долей ответивших «определенно да» и «скорее да»

Fig. 3. Dynamics of confidence of Russians that the Russian special services, the Ministry of Internal Affairs and the authorities will be able to protect the population from new terrorist acts (2005-2018), the sum of the shares answered «Definitely yes» and «Rather yes»

\footnotetext{
${ }^{1}$ График построен на основании данных из источника: Проблема терроризма в представлениях россиян // Левада-Центр. Пресс-выпуск 12.02.2014 г. URL: https://www.levada.ru/2014/02/12/problema-terrorizma-v-predstavleniyah-rossiyan/ (дата обращения: 15.08.2019).

${ }^{2}$ График построен на основании данных из источника: Террористическая угроза на сирийском фоне // ВЦИОМ. Прессвыпуск 11.09.2018 г. URL: https://wciom.ru/index.php?id=236\&uid=9302 (дата обращения: 15.08.2019).
} 
Наибольшую ответственность за обеспечение безопасности страны от угроз терроризма в 2005 году россияне возлагали на ФСБ, Правительство, Президента РФ и полицию. Опираясь на результаты опросов Общественного мнения Левада-Центра и ВЦИОМ, проанализируем динамику оценок россиян их уверенности в том, смогут ли российские спецслужбы, МВД и власти защитить население от новых терактов (см. рис. 3).

Данные о динамике в рассматриваемый период времени указывают на тенденцию медленного роста уверенности россиян в способности силовых структур защитить население от новых терактов, что при соотнесении со статистикой количества зарегистрированных терактов в России может представляться определенным парадоксом (рис. 4).

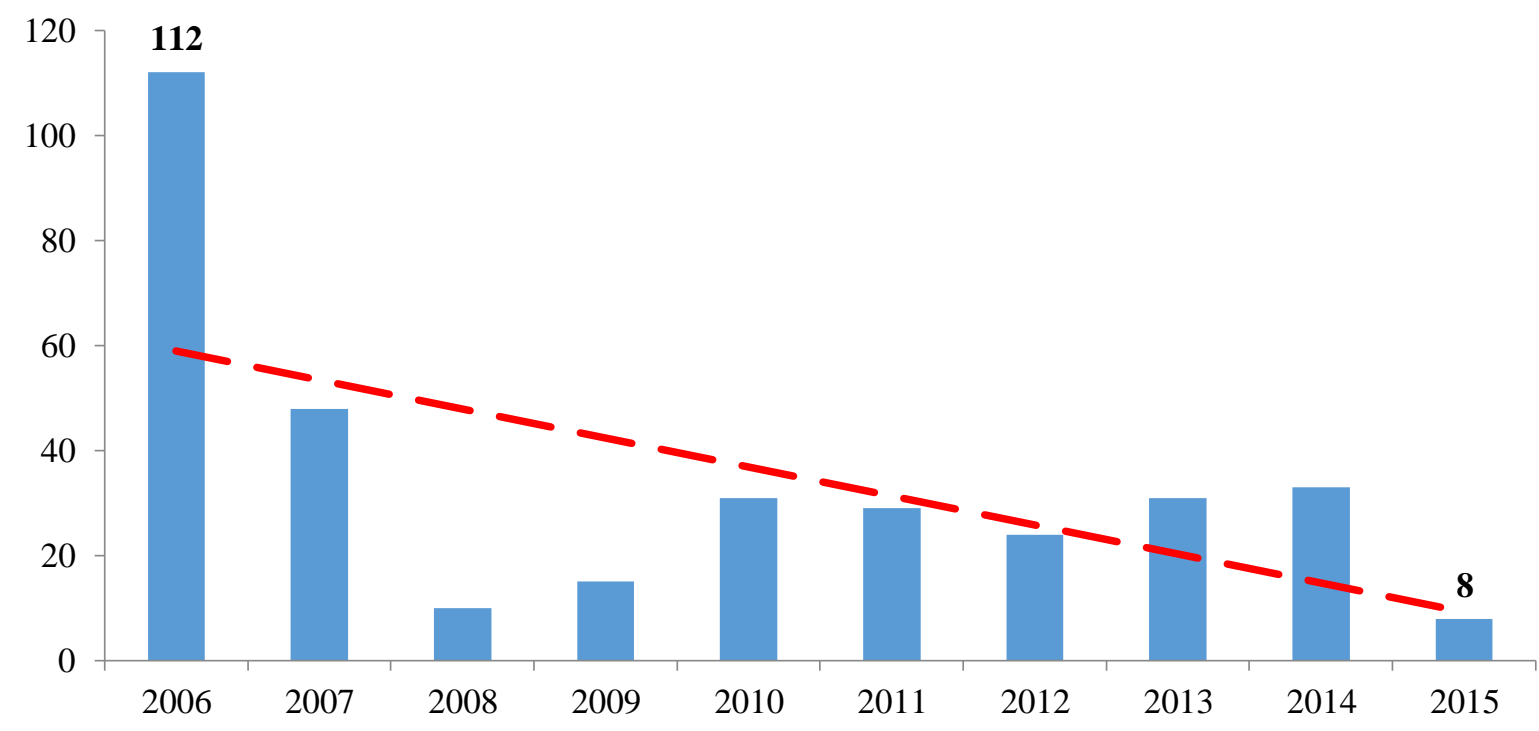

Рис. 4. Динамика количества зарегистрированных террористических актов в Российской Федерации (2005-2015) ${ }^{1}$

Fig. 4. Dynamics of the number of registered terrorist acts in the Russian Federation (2005-2015)

Тенденция резкого снижения количества терактов в России за десятилетие на фоне активизации и роста мощи международных террористических организаций свидетельствует о достаточной эффективности российских спецслужб в противодействии терроризму, что подтверждается и публичными отчетами о деятельности ФСБ. В интервью «Российской газете», отвечая на вопрос о готовности российских спецслужб к отражению угроз терроризма и экстремизма, Директор ФСБ России А. В. Бортников подчеркнул, что в России выстроена общегосударственная система противодействия терроризму, в функции которой входят не только борьба с терроризмом и минимизация его последствий, но и профилактика терроризма и экстремизма. «Ведется профилактическая работа по противодействию радикализации населения и его вовлечения в террористическую деятельность..,, осуществляются мероприятия по противодействию и профилактике распространения идеологии терроризма: ...пресечена деятельность свыше 300 структурных подразделений организаций террористической и экстремистской направленности...; из незаконного оборота изъято значительное количество оружия, боеприпасов и взрывчатых веществ...; ведется работа по перекрытию каналов переброски боевиков международных террористических организаций из зон вооруженных конфликтов на Ближнем Востоке, в Северной Африке и афганопакистанской зоне в Россию, а также выез- 
да в эти регионы российских граждан; ...проводятся фильтрационные мероприятия в миграционных потоках. Приоритетным направлением деятельности ФСБ по противодействию терроризму сегодня является вскрытие «спящих ячеек» террористических и экстремистских организаций, a также противодействие боевикамодиночкам, атаки которых в последнее время произошли уже во многих государствах» ${ }^{1}$.

Эксперты в области правового обеспечения национальной безопасности отмечают концептуальные изменения в подходах «к организации деятельности по минимизации и (или) ликвидации последствий проявлений терроризма, которая планируется заблаговременно, исходя из прогнозов возможных последствий террористических актов» (Меркурьев, Агапов, 2016: 52).

Об успехах в противодействии терроризму свидетельствуют и результаты социологических исследований специфики деятельности спецслужб в отдельных регионах, например, в Саратовской области (Щебланова, 2016).

Полученные результаты позволяют утверждать, что институциональные субъекты противодействия терроризму характеризуются достаточно высоким уровнем адаптированности к риску терроризма. Содержательное развитие как законодательства, так и механизмов противодействия свидетельствуют об активной стратегии адаптации институциональных субъектов к рискогенной среде.

Однако важнейший ресурс повышения адаптированности населения к риску терроризма, а именно - доверие к институциональным противодействующим субъектам, в полной мере не реализуется.

Выявленное противоречие между за-

\footnotetext{
${ }^{1}$ ФСБ расставляет акценты. Интервью главного редактора «Российской газеты» В. А. Фронина с Директором ФСБ России А. В. Бортниковым // Российская газета. Федеральный выпуск № 288 (7454). 19.12.2017 г. URL: https://rg.ru/2017/12/19/aleksandr-bortnikov-fsb-rossiisvobodna-ot-politicheskogo-vliianiia.html (дата обращения: 15.08.2019).
}

фиксированными успехами спецслужб и тенденцией медленного роста уверенности населения России в способности силовых структур защитить от новых терактов, на наш взгляд, представляет собой научную проблему, требующую специального изучения. Целевой анализ причин рассматриваемого противоречия на сегодняшний день оказывается невозможным из-за отсутствия данных - позволяющие его осуществить исследования не проводятся ни социологами, ни представителями смежных дисциплин, ни экспертами из силовых ведомств (по крайней мере, в публичном доступе результаты подобных исследований не обнаружены). В рамках статьи продемонстрируем обобщение результатов социологических исследований, целью которых было выявление представлений экспертов и населения России о причинах недостаточной эффективности деятельности российских спецслужб, которые мы интерпретируем как требующий развития резерв механизмов противодействия, так и ресурс адаптации к риску терроризма.

Причинами неэффективности деятельности спецслужб по предупреждению и смягчению последствий терактов эксnерты называют недостаточное внимание «предупредительно-профилактической работе»; отсутствие специальной подготовки сотрудников власти, образовательных учреждений по защите от терроризма; невыполнение на местах принятых решений вышестоящих органов; отсутствие в образовательных учреждениях обучающих курсов и воспитательных программ по антитерроризму; недостаточное привлечение ученых (социологов, психологов) к решению проблем противодействия терроризму (Щебланова, 2016).

По данным опросов населения, основными причинами неэффективности деятельности спецслужб по противодействию терроризму являются: нехватка квалифицированных кадров, недостаточность финансирования, неразвитость сети осведомителей, слабая координация действий силовых структур, недостаточное взаимо- 
действие с зарубежными специалистами, отсутствие прочной опоры в обществе в борьбе с терроризмом - Институт социологии РАН, 2005; коррупция в правоохранительных органах (Грязнова, 2005); отсутствие возможностей у населения или его нежелание оказывать помощь властным и силовым структурам (Роговая, 2015).

Гражданское участие как ресурс противодействия терроризму. В системе противодействия терроризму гражданское население выступает специфическим субъектом, с одной стороны, является главной «мишенью» воздействия террористов, с другой, «априори приписывается к сторонникам государственных структур» (Грязнова, 2005: 17). Как было показано выше, население и эксперты солидарны в том, что гражданское

Широкое привлечение населения к работе спецслужб по противодействию терроризму

Действенная борьба с коррупцией
Формирование культуры терпимости и
компромиссов

Политическая стабильность

Подъем экономики, рост социальной защищенности

Использование внутренних войск (полиции)

Операции силами спецподразделений ФСБ

Операции с участием армии участие является важным фактором повышения эффективности процесса противодействия терроризму. В рамках методологии анализа адаптационных процессов участие населения в борьбе с терроризмом является важным адаптационным ресурсом и показателем активной стратегии адаптации. Следовательно, определение антитеррористического потенциала россиян представляется актуальной научной и практической задачей.

Одной из целей опроса Института социологии РАН 2005 года являлось фиксирование представлений респондентов о важности различных мер противодействия терроризму и определение места привлечения населения к работе спецслужб по противодействию терроризму в рейтинге этих мер (рис. 5).

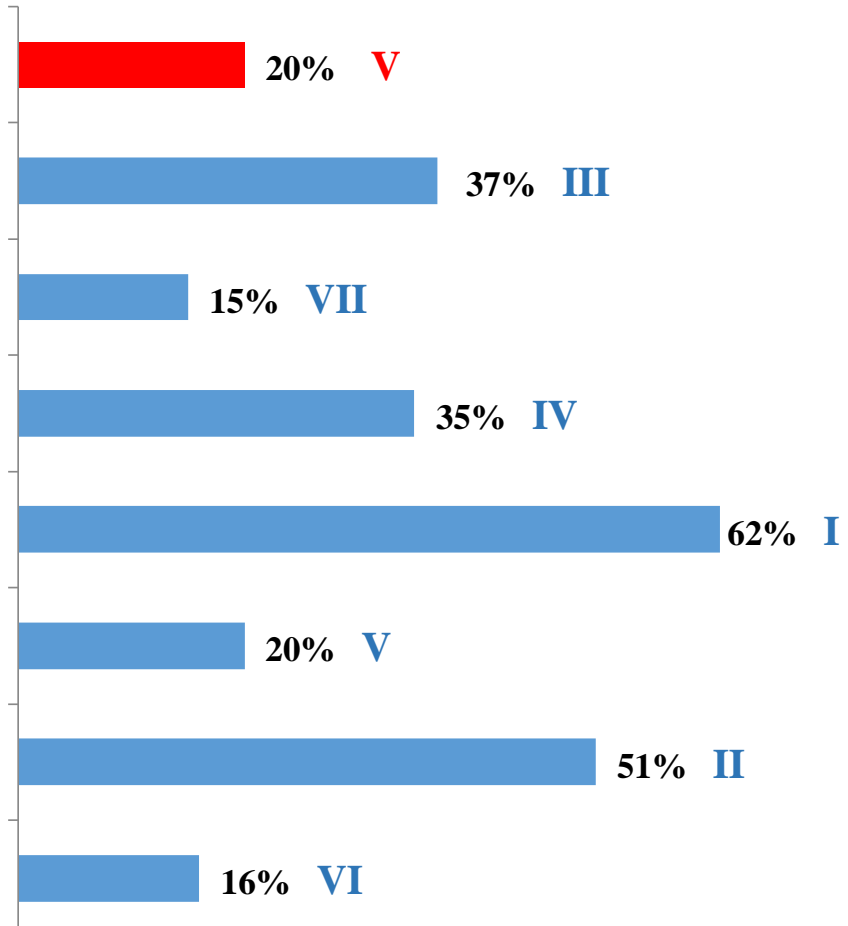

Рис. 5. Оценка россиян важности мер противодействия терроризму (рейтинг), $\%$ от количества опрошенных

Fig. 5. Russians' assessment of the importance of counter-terrorism measures (rating), $\%$ of the number of respondents

В представлении россиян в 2005 году в рейтинге важности мер противодействия терроризму привлечение населения к работе спецслужб занимало среднюю позицию.
Однако необходимо учитывать тот факт, что гражданское участие в противодействии терроризму по важности оценивается населением так же, как и деятельность МВД. 
На наш взгляд, часть населения, осознающая важность гражданского участия, может рассматриваться как социальная база противодействия терроризму - та самая потенциальная опора в обществе, отсутствие которой рассматривалось выше в числе факторов, снижающих эффективность борьбы с терроризмом.

По социально-демографическим характеристикам в этой группе населения больше женщин, респондентов со средним и средним специальным образованием; преобладают люди среднего возраста и проживающие в областных и районных центрах. Осознающие важность гражданского участия в противодействии терроризму достаточно равномерно распределены по российским регионам, в которых проводился опрос.

Данные более позднего исследования, полученные коллегами из МГЛУ в 2011 году, подтвердили неизменность социально-демографических особенностей «предрасположенных» к участию в противодействии терроризму россиян (Шалупенко, 2012). Однако нельзя исключать возможность динамики социального портрета антитеррористического потенциала населения России в более поздний период, так как подобного рода исследования после 2011 года нам не известны.

Ниже целесообразно подробнее обозначить результаты упомянутого исследования МГЛУ, так как оно является уникальным целевым исследованием готовности россиян к противодействию терроризму. «Готовность к противодействию терроризму» авторы исследования интерпретировали как «специфическое состояние человека, отражающее его подготовленность и предрасположенность любыми способами противостоять организованным действиям насильственного характера, направленным на устрашение населения, оказание давления на представителей органов государственной власти и местного самоуправления при принятии политически и социально значимых решений» (Шалупенко, 2012: 43). Обобщенный результат, полученный коллегами, представим на рис. 6.

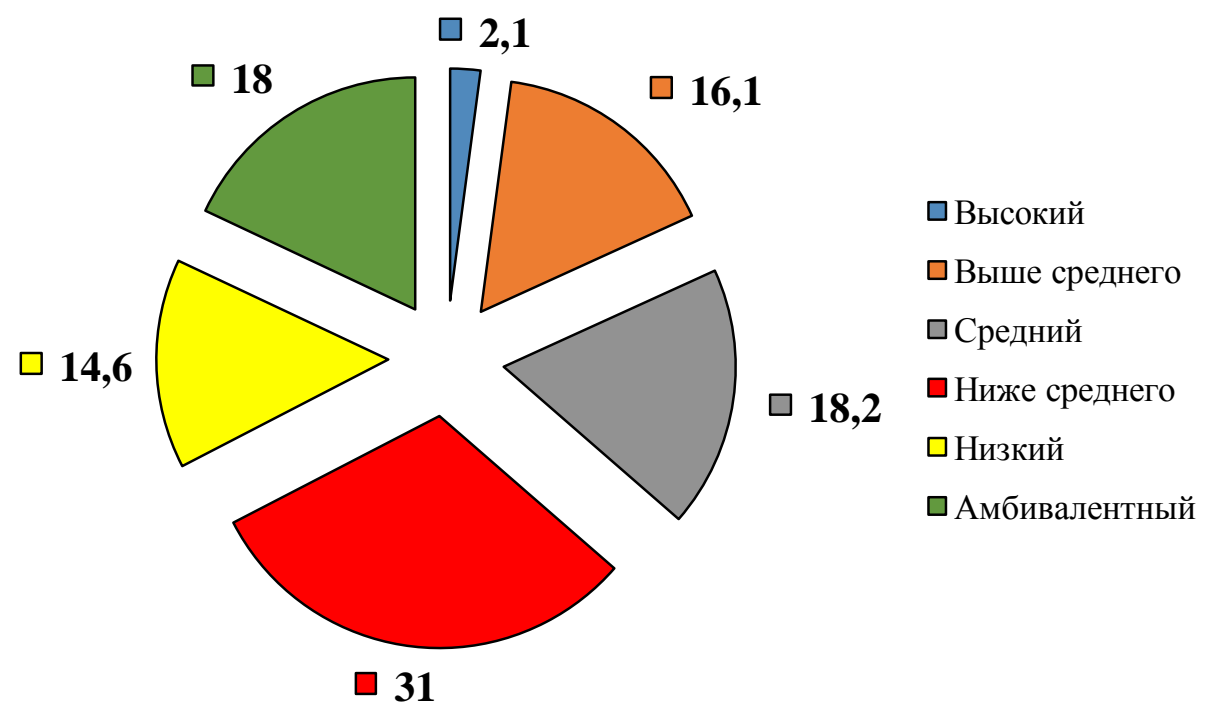

Рис. 6. Общий уровень готовности населения России к противодействию терроризму (результат сопоставления различных уровней подготовленности и предрасположенности по методу логического квадрата) ${ }^{1}$

Fig. 6. The general level of readiness of the population of Russia to counter terrorism (the result of comparing different levels of preparedness and predisposition by the method of the logical square)

${ }^{1}$ Диаграмма построена на основе данных из источника (Шалупенко, 2012: 47-48). 
Сопоставление результатов нашего исследования 2005 года с результатами коллег показывает, что в рассматриваемый шестилетний период потенциал гражданского участия населения России в борьбе с терроризмом как механизм противодействия, так и адаптационный ресурс, оставался недостаточно развитым. Население как субъект противодействия характеризуется пассивной стратегией адаптации к риску терроризма. Полагаем, выявленные тенденции не только являются фактором, тормозящим процесс противодействия терроризму, но и могут обусловливать низкий уровень адаптированности гражданского общества к рискогенной среде.

Заключение (Conclusions). Предложенный в статье подход к противодействию терроризму как процессу институционально-гражданской адаптации к рискогенной среде, позволил зафиксировать адаптационную асимметрию в скорости и успешности адаптации двух субъектов противодействия: социальных институтов и гражданского общества, которая является важным фактором, тормозящим процесс противодействия в целом. В связи с этим считаем актуальной задачу поиска факторов, детерминирующих баланс адаптационных стратегий и ресурсных потенциалов рассматриваемых субъектов.

Институцииональные субъекты характеризуются достаточно высоким уровнем адаптированности, высокой скоростью наращивания адаптационного потенциала и активной адаптационной стратегией, обусловленной действующим механизмом противодействия терроризму.

Развитие российской законодательной антитеррористической базы способствовало выведению процесса противодействия терроризму на новый уровень, характеризующийся согласованностью оперативно-розыскной работы и правоприменительной практики. Дальнейшее развитие законодательной базы требует особого внимания к превентивным мерам противодействия - профилактике и предотвращению преступлений террори- стического характера. На наш взгляд, важнейшим фактором, способствующим накоплению научного знания и практического опыта борьбы с терроризмом, мог бы стать «мониторинг эффективности противодействия терроризму», обеспечивающий обратную связь институциональных субъектов противодействия и гражданского общества. Наличие научно обоснованной оценки реализации решений в сфере противодействия терроризму существенным образом сохранит силы и средства участников процесса, будет способствовать его эффективности в целом и послужит основой коммуникации субъектов противодействия. Включение в мониторинг показателей, связанных с оценкой населением антитеррористической деятельности институциональных субъектов, откроет возможность научного обоснования факторов повышения доверия силовым и властным структурам и разработки рекомендаций для формирования их положительного имиджа, что впоследствии может привести к снижению уровня тревожности населения в отношении террористической угрозы, а значит, будет способствовать росту адаптированности населения к риску терроризма.

Население характеризуется низким уровнем адаптированности к риску терроризма, неразвитостью адаптационного потенциала и пассивной стратегией адаптации, обусловленной недооценкой важности гражданского участия и стремлением переложить ответственность за противодействие терроризму на институциональные субъекты. Необходимым представляется углубленное изучение потенциала гражданского участия в противодействии терроризму; выявление факторов, способствующих наращиванию адаптационных ресурсов населения, формированию активных установок на участие в профилактике и противодействии терроризму, росту готовности разделить ответственность за снижение риска терроризма в России с институциональными субъектами. 


\section{Список литературы}

Аккаева Х. А. Новые тенденции законодательства об экстремизме и терроризме в Российской Федерации // Исторические, философские, политические и юридические науки, культурология и искусствоведение. Вопросы теории и практики. 2015. № 10-2. С. 16-18.

Анищенко К. Ф. Правовые основы противодействия терроризму в России: краткий анализ Федерального закона «О противодействии терроризму» // Теория и практика общественного развития. 2006. № 2. С. 87-92.

Бутаев М. Я. Использование в доказывании результатов оперативно-розыскной деятельности при расследовании уголовных дел о преступлениях террористической направленности // Юридическая наука и правоохранительная практика. 2015. № 3. С. 106-110.

Грязнова О. Массовое отношение к терроризму как показатель политической культуры жителей России // Вестник общественного мнения. 2005. № 3. С. 16-29.

Козырева П. М. Процессы адаптации и эволюция социального самочувствия россиян на рубеже XX-XXI веков. М.: Центр общечелх цен-ей, 2004.

Косарев М. Н. Состояние и перспективы противодействия терроризму в России: теоретические и практические аспекты // Вестник Уральского юридического института МВД России. 2016. № 4. С. 37-41.

Кочои С. М. Пробелы в законодательстве о терроризме и предложения по их устранению // Всероссийский криминологический журнал. 2016. Т. 10, № 4. С. 740-749.

Маркин В. В. Формирование российской идентичности как фактор противодействия идеологии экстремизма и терроризма: региональный аспект // Власть. 2014. Т. 22, № 6. C. 120-127.

Меркурьев В. В., Агапов П. В. Вопросы регламентации действий руководителя контртеррористической операции // Мониторинг правоприменения. 2016. № 2. С. 49-58.

Мозговая А. В., Шлыкова Е. В. Социальные ресурсы и адаптация к риску: выбор стратегии (на примере социальной общности в ситуации конкретного риска) // Социологическая наука и социальная практика. 2014. № 4. C. 25-49.

Павлинов А. В. Законодательное обеспечение борьбы с терроризмом и другими проявлениями экстремистской деятельности: исчер- паны ли ресурсы? // Труды Института государства и права Российской академии наук. 2014. № 3. С. 123-130.

Роговая А. В. Локализация противодействия идеологии экстремизма и терроризма в муниципальном образовании // Власть. 2015. № 1. C. 124-130.

Российское общество и вызовы времени. Книга пятая / Под ред. М. К. Горшкова, В. В. Петухова. М.: Весь Мир, 2017.

Сембекова Б. Р. Терроризм - угроза национальной безопасности: стратегия антикриминальной безопасности личности // Society and Security Insights. 2018. T. 1, № 4. C. 37-47.

Соболев В. А. Противодействия терроризму в XXI веке // Обозреватель - Observer. 2010. № 8. C. 20-30.

Шалупенко В. В. Готовность граждан России к противодействию терроризму // Социологические исследования. 2012. № 12. С. 42-49.

Шлыкова Е. В. Субъективная оценка личной безопасности как показатель адаптированности к рискогенной среде // Социологический журнал. 2018. Т. 24, № 3. С. 56-75.

Щебланова В. В. Институциональные формы превенции террористических угроз // Конфликты в современном мире: международное, государственное и межличностное измерение. Мат. V Междунар. науч. конф. / Отв. ред. Ю. О. Бронникова, Л. В. Мясникова, Т. Г. Фирсова. М.: Перо, 2016. С. 143-149.

Щебланова В. В. Социальное конструирование проблем терроризма // Вестник Нижегородского университета им. Н. И. Лобачевского. Сер.: Социальные науки. 2012. № 2. C. 103-107.

Щебланова В. В. Террористические действия и их последствия в ракурсе концепций социального действия // Вестник СГТУ. 2013. № 1. С. 268-272.

Яхьяев М. Я., Исаева Э. Г., Сутаева А. Р. Социально-психологические аспекты противодействия терроризму в мультикультурном пространстве // Социальная психология и общество. 2018. Т. 9, № 2. С. 46-59.

\section{References}

Akkaeva, H. A. (2015), "New tendencies of legislation on extremism and terrorism in the Russian Federation", Istoricheskie, filosofskie, politicheskie i yuridicheskie nauki, kul'turologiya $i$ iskusstvovedenie. Voprosy teorii i praktiki, (10-2), 16-18. (In Russian). 
Anishhenko, K. F. (2006), "Legal basis of counter-terrorism in Russia: a brief analysis of the Federal Law 'On counter-terrorism'", Teoriya $i$ praktika obshhestvennogo razvitiya, (2), 87-92. (In Russian).

Butaev, M. Ya. (2015), "The use of detective activities' results in proving when investigating cases of terrorist crimes", Yuridicheskaya nauka i pravooxranitel'naya praktika, (3), 106110. (In Russian).

Gryaznova, O. (2005), "Mass attitude to terrorism as an indicator of the political culture of the citizens of Russia", Vestnik obshchestvennogo mneniya, (3), 16-29. (In Russian).

Kozyreva, P. M. (2004), The processes of adaptation and evolution of social well-being of Russians at the turn of XX-XXI centuries, Centr obshchechelovecheskih tsennostey, Moscow, Russia. (In Russian).

Kosarev, M. N. (2016), "The status and prospects of counter-terrorism in Russia: theoretical and practical aspects", Vestnik Ural'skogo yuridicheskogo instituta MVD Rossii, (4), 37-41. (In Russian).

Kochoi, S. M. (2016), "The gaps in antiterrorism legislation and proposals for bridging them", Vserossijskij kriminologicheskij zhurnal, 10 (4), 740-749. (In Russian).

Markin, V. V. (2014), "Formation of Russian identity as a factor of counteraction to ideology of extremism and terrorism: regional aspect", Vlast', 22 (6), 120-127. (In Russian).

Merkur'ev, V. V. and Agapov, P. V. (2016), "Issues of legal regulation of the plan of action of the head of a counter-terrorist operation", Monitoring pravoprimeneniya, (2), 49-58. (In Russian).

Mozgovaya, A. V. and Shlykova, E. V. (2014), "Social resources and adaptation to risk: the choice of strategy (by the example the social community in the situation of particular risk)", Sociologicheskaya nauka i social'naya praktika, (4), 25-49. (In Russian).

Pavlinov, A. V. (2014), "Legislative support of the fight against terrorism and other extremist activities: exhausted whether resources?", Trudy Instituta gosudarstva i prava Rossijskoj akademii nauk, (3), 123-130. (In Russian).

Rogovaya, A. V. (2015), "Localization of counteraction to the ideology of extremism and terrorism in the municipality", Vlast', (1), 124-130. (In Russian).

Russian Society and Challenges of The Time. Book Five (2017), in Gorshkov, M. K. and
Petuhov, V. V. (eds.), Ves' Mir, Moscow, Russia. (In Russian).

Sembekova, B. R. (2018), "Terrorism - a threat to national security: the strategy of anticriminal security of the person", Society and Security Insights, 1 (4), 37-47. (In Russian).

Sobolev, V. A. (2010), «Countering terrorism in the XXI century», Obozrevatel' - Observer, (8), 20-30. (In Russian).

Shalupenko, V. V. (2012), "The willingness of Russian citizens to countering terrorism", Sociologicheskie issledovaniya, 12, 42-49. (In Russian).

Shlykova, E. V. (2018), "Subjective assessment of personal security as an indicator of adaptation to a risky environment", Sociologicheskij zhurnal, 24 (3), 56-75. (In Russian).

Shheblanova, V. V. (2016), "Institutional forms of prevention of terrorist threats", in Bronnikova, Yu. O., Myasnikova, L. V., Firsova, T. G. (eds.) Conflicts in the modern world: international, state and interpersonal dimension. Proceedings of the $V$ International scientific conference, Pero, Moscow, Russia. (In Russian).

Shheblanova, V. V. (2012), "The social construction of the problems of terrorism", Vestnik Nizhegorodskogo universiteta im. N.I. Lobachevskogo. Seriya: Social'nye nauki, (2), 103-107. (In Russian).

Shheblanova, V. V. (2013), "Terrorist actions and their consequences regarding the concepts of social actions", Vestnik SGTU, (1), 268-272. (In Russian).

Yax'yaev, M. Ya., Isaeva, E'. G. and Sutaeva, A. R. (2018), "Socio-psychological aspects of counteraction to terrorism in multicultural space", Social'naya psixologiya i obshhestvo, 9 (2), 46-59. (In Russian).

Конфликты интересов: у автора нет конфликта интересов для декларации.

Conflicts of Interest: the author has no conflict of interest to declare.

Шлыкова Елена Викторовна, ведущий научный сотрудник Института социологии Федерального научно-исследовательского социологического центра Российской академии наук, кандидат социологических наук.

Elena V. Shlykova, Leading Research Fellow, Institute of Sociology, Federal Center for Theoretical and Applied Sociology, Russian Academy of Sciences, PhD in Sociology. 